\title{
Use of Renewable Energy Sources for Energy Generation in Rural Areas in the Island of Crete, Greece
}

\author{
John Vourdoubas
}

\section{ABSTRACT}

Use of renewable energies in rural areas in the island of Crete, Greece has been investigated. Crete has rich indigenous renewable energy resources which are currently utilized for covering part of its energy requirements. Various renewable energy technologies used for heat and electricity generation in the island have been examined. Solar energy, wind energy, hydro power, biomass, and low enthalpy geothermal energy are already used. The total installed electric power of renewable energies in Crete, located mostly in rural areas, is approximately at $30 \%$ of the total electric power installed. They currently generate more than $20 \%$ of the island's annual electricity needs. More renewable energy applications are foreseen in the future in rural areas in Crete as soon as its electric grid will be interconnected with the country's continental grid. New renewable energy technologies, which are not currently used, could generate in the future heat, cooling, electricity, and vehicle's fuels in the island. Their use will have positive impacts including the promotion of energy investments, lower use of imported and polluting fossil fuels, de-carbonization of the island's energy sector as well as creation of new local jobs. It is indicated that the rich renewable energy resources in Crete could provide almost all of its annual energy needs. This will result in Crete's transformation to a low or zero carbon economy in accordance with $\mathrm{EU}$ targets for zero carbon emissions in the next decades complying with the global goal for climate change mitigation.

Keywords: Crete, Greece, electricity, heat, renewable energies, rural areas.

Published Online: November 30, 2020

ISSN: $2684-446 \mathrm{X}$

DOI :10.24018/ejgeo.2020.1.6.88

John Vourdoubas*

Mediterranean Agronomic Institute of Chania, Greece.

(e-mail: vourhome@ ${ }^{@}$ otenet.gr)

*Corresponding Author

\section{INTRODUCTION}

Climate change threatens the stability and prosperity of modern developed societies as well as the efforts of developing countries to improve their economic and human development. One of the major pillars in our global effort to promote sustainability is the de-carbonization of our economy replacing the use of fossil fuels with renewable energies (REs). Island of Crete, Greece has abundant renewable energy resources including solar and wind energy. During the last decades a rapid growth of their use for heat and power generation has been recorded in the island. Additionally, further development is foreseen in the future when more RE technologies will become costeffective and broadly commercialized. Current applications of REs in Crete include the use of solar energy, wind energy, hydropower, solid and gaseous biomass, and low enthalpy geothermal energy. Integrated development of REs with other economic activities, particularly in agriculture and tourism, is important for Crete's prosperity. Their use increases island's sustainability, reduces its carbon footprint, and assists its transition to low, or zero, carbon economy. The most of existing RE systems in Crete are located in rural areas. The study of different RE systems installed so far gives an overview of their current status in the island. Examination of future applications of REs in Crete will demonstrate the capability of these benign energy systems to cover the majority, if not all, of the island's annual energy requirements.

\section{LITERATURE SURVEY}

\section{A. Use of Renewable Energies in Islands}

Ciriminna et al. [1] have studied the use of solar energy for Sicily's remote islands. The authors stated that these islands share a number of pioneering achievements in the utilization of solar energy including the use of solar electricity in water desalination. They also mentioned that higher penetration of REs in the Sicily's islands requires the removal of existing barriers. Franzitta et al. [2] have analyzed the electrical energy sector in the Maltese islands using REs for increasing their sustainability. The authors proposed the use of wave energy systems as well as offshore solar-PV systems for electricity generation. They stated that installing wave farms at $130 \mathrm{MW}$ will generate about $5.7 \%$ of Malta's energy needs while the installation of 
$60 \mathrm{MW}$ off-shore solar-PV plants will generate about $4.4 \%$ of its annual energy needs. Kougias et al. [3] have investigated the use of REs in non-interconnected Mediterranean islands for creating a sustainable energy system. The authors mentioned that the electricity production cost will be decreased with the increased use of REs in islands. They also stated that the increasing use of indigenous REs replacing conventional fossil fuels will result in many economic and environmental benefits. A catalogue of good practices for EU islands which are in the stage of energy transition has been published, 2019 [4]. Successful projects from ten islands in all European territories are presented. It is mentioned that the new EU's clean energy package puts citizens in the core of the energy transition which is interesting to island communities. A report on islands as test beds for innovative energy solutions has been published [5]. The report promotes the idea of "smart islands" offering an integrated approach to island's development. Topics related with smart grids for smart energy solutions, storage of electricity, energy efficient street lighting and electric vehicles infrastructure are analyzed in the report. Tsekeris [6] has studied the energy transition of the Greek islands with inter-connected grids. The author mentioned that high REs penetration in islands, which should be higher than $50-60 \%$, is required. He also stated that new technological solutions should be used including novel RE applications, energy storage systems and electrification of transportation including electrified ships. Christopoulou et al. [7] have explored the biomass energy potential in the island Samothrace, Greece. The authors studied the possibility of utilizing the local biomass resources for increasing the energy autonomy in the island. They suggested various measures including the utilization of locally produced olive pits the promotion of local energy crops the recycling of solid organic wastes combined with biogas production and the utilization of local forest biomass resources. Ioakimidis et al. [8] have investigated the integration of seawater pump-storage in the electricity system of the island Sao Miguel, Azores. The authors mentioned that Sao Miguel is an isolated island with high REs potential. They also stated that storage of electricity generated by REs in seawater pump storage systems increases REs penetration in the island's electric system reducing the fossil fuels use and the resulting greenhouse gas (GHG) emissions. Dorotic et al. [9] have studied the use of intermittent REs for achieving a $100 \%$ carbon neutral island focusing on the Croatian island "Korcula" populated by 15,521 inhabitants. The authors mentioned that only solar and wind energy were utilized while total electricity import and export were balanced achieving carbon neutrality in the island. Their results indicated that the lowest cost solution included the installation of $40 \mathrm{MW}$ wind parks and $6 \mathrm{MW}$ solar power plants in the island. Michalakakou et al. [10] have reported on the applications of renewable energy sources (RES) in the Greek islands of the South Aegean Sea. The authors analyzed the potential of various RES in these islands including solar thermal and solar-PV energy, wind energy, biomass, and geothermal energy. Use of REs in islands as a pathway to their prosperity has been reported,
2015 [11]. It is mentioned that in most small islands a combination of RES can meet the majority, if not all, of the domestic energy needs. Successful applications of REs in various small islands worldwide are stated while islands offer the possibility to demonstrate the effectiveness of various REs solutions.

\section{B. Use of Renewable Energies in Crete}

Gkouskos et al. [12] have reported on the activities of Technical University of Crete in solar energy applications in Crete. The authors mentioned that many solar photovoltaic (solar-PV) systems exist in the island while their installed power is lower than the installed power of wind farms. They also stated that two solar thermal cooling systems have been installed in two Cretan hotels while four licenses for the installation of solar thermal power plants have been approved in the island. Gigantidou [13] has presented the current status of the electrical system in Crete. The author stated that due to high solar and wind energy potential in the island many wind farms and solar-PV systems have been installed during the recent years. She also mentioned that in 2011 and 2012 solar and wind electricity had a share at approximately $20 \%$ in the overall island's electricity generation. Kougias et al. [14] have calculated the potential to install large scale solar-PV systems in five Mediterranean islands (Crete, Cyprus, Sicily, Sardinia, Corsica). The authors proposed the installation of solar-PV panels in existing infrastructure of water dams as well as over irrigation canals. They estimated that in the abovementioned five Mediterranean islands solar-PVs with nominal power at 93 MWp could be installed in water dams while in irrigation canals additional $60 \mathrm{MWp}$. Katsaprakakis et al. [15] have investigated the technical and economic aspects for the energy transition of the electric system in Crete from fossil fuels to REs. The authors mentioned that high penetration of REs in the energy system of Crete can be achieved with electricity storage plants. They also stated that the combination of wind parks with pump hydro storage systems could allow more than $90 \%$ REs penetration in the electric system of Crete. Vourdoubas [16] has studied the present and future uses of biomass for energy generation in the island of Crete, Greece. The author stated that solid biomass is currently used mainly for heat than for power generation. He also mentioned that small quantities of electricity are generated with biogas while liquid biofuels are not currently produced in the island. Alatzas et al. [17] have assessed the potential of biomass resources for energy generation in various Greek regions. The authors calculated the biomass resources in the regions of Crete, Thessaly and Peloponnese which are mainly based in olive pits, olive pruning and cotton ginning remnants. They also implemented a case study for a small co-generation of heat and power (CHP) gasification plant in Messenia, Peloponnese which is characterized with high biomass potential. Nikolaou et al. [18] have investigated the use of the site "Potamon" dam in Crete, Greece for the creation of a hydro pump storage system of the rejected electricity from existing wind farms in the island. The authors mentioned that the water pump storage system could store the rejected wind electricity which is currently lost due to the fact that 
the electric grid of Crete is autonomous. They also stated that the electricity stored in this system and utilized later corresponds approximately at $2 \%$ of the annual electricity consumption in the island. Biogas production derived from municipal wastes in European islands has been investigated through the EU funded project BIORES, 2010 [19]. The project was focused on small scale decentralized energy production from RES combined with sustainable waste management with reference to six EU islands including Crete. Fantidis et al. [20] have assessed the wind energy potential in Greece using a small wind turbine at $2.5 \mathrm{KW}$ installed in various sites of the country and the HOMER software. The authors mentioned that Greece has high wind energy potential while the Southern part of the country, including Crete, and Aegean islands has higher wind energy potential than Northern Greece. A report regarding the electric system in Crete has been published by HEDNO, 2018 [21]. The report mentioned that the electricity generation in Crete, during 2018, was 3,043 GWh while generation by REs had a share at $21 \%$ in total electricity generation. It is also stated that the installed power of wind parks was 200.3 MW, of solar-PVs at 95.5 MWp and of small hydro plants at $0.6 \mathrm{MW}$. The total installed power of REs was approximately at $30 \%$ of the total installed power in the island.

\section{Use of Various Renewable Energies}

Argiriou et al. [22] have studied the solar thermal market in Greece. The authors stated that the solar thermal market in the country is one of the most developed worldwide. They mentioned that there are various reasons for its success including the incentives on the demand and the supply sides the quality assurance practices as well as the positive role of the manufacturers. Karagiorgas et al. [23] have reported on industrial solar thermal applications in Greece. The authors mentioned that during recent years existing industrial solar thermal applications offer economic, environmental and energy benefits. They also stated that good potential for future applications exists in sectors like agro-food, textiles, chemicals, and beverages while they described eight successful solar thermal applications in the Greek industry. Scarlat et al. [24] have studied the developments and perspectives of biogas in Europe. The authors mentioned that production of biogas in Europe represents $50 \%$ of the global biogas production. They also stated that it is currently used for heat and electricity production as well as for transportation fuel. Europe is the world leader in biogas electricity generation as well as in bio-methane production used as vehicle's fuel and for injection in the natural gas grid. Raboni et al. [25] have studied the production and uses of biogas in Europe. The authors stated that Germany, England, Italy, and France are the EU leaders in biogas production. They also mentioned that biogas production in Germany is based in anaerobic digestion (or co-digestion) of organic matter while in England in biogas produced in landfills and in sewage treatment plants. Aggarwal et al. [26] have studied the modern trends in geothermal energy utilization focusing on ground source heat pumps (GSHPs) used for air-conditioning in buildings in India and worldwide. The authors mentioned that air-conditioning in buildings has a high share in their overall energy consumption. They also stated that GSHPs have a huge potential for air-conditioning and providing domestic hot water (DHW) in buildings assisting in the achievement of sustainable development goals as well as in reducing the global warming potential. A report regarding off-grid renewable energy systems has been published, 2015 [27]. The report mentioned that a significant number of households, mainly in developing countries, are served through off-grid renewable energy systems. It also stated that there are few thousands mini-grids in operation based on REs that are not connected to the main electric grid. These mini-grids are based on solar-PVs, small wind turbines, small hydro power plants and rice husks gasification plants. Lund et al. [28] have reviewed the current development of geothermal energy worldwide. The authors mentioned that the distribution of thermal energy used per category is approximately $55.3 \%$ for GSHPs, $20.3 \%$ for bathing and swimming, $15.0 \%$ for space heating including district heating, $4.5 \%$ for greenhouses and the rest for other uses. A report on biomass production, supply and uses in EU has been published, 2018 [29]. The report mentioned that total annual agricultural biomass production in EU was estimated at $956 \mathrm{Mt}$ of dry biomass while $46 \%$ of it was by-products and residues which could be used for energy generation. Total forest biomass produced annually in EU was estimated at $510 \mathrm{Mt}$ while $48 \%$ of it was used for energy generation.

Aim of the current work is the investigation of current applications of renewable energies for heat and power generation in rural areas in the island of Crete, Greece.

After the literature review current applications in solar energy, wind energy, hydroelectricity, biomass, and geothermal energy in rural areas in Crete are stated. Applications of new RE technologies in the island which are foreseen in the future are mentioned followed by the discussion of the findings and the conclusions drawn.

\section{SOLAR ENERGY APPLICATIONS}

\section{A. Solar Thermal Energy}

Solar energy is extensively used during the last decades in Crete for DHW production with simple solar thermoshiphonic systems and flat plate collectors. Water temperatures in the range of $50-70^{\circ} \mathrm{C}$ can be achieved covering the majority of DHW needs in residential buildings and most of the needs in various hotels. Due to high solar irradiance in Crete the majority of residential buildings as well as the summer-operating hotels are using solar thermal systems for hot water production. The technology is mature, reliable, broadly used and cost-effective. Use of solar thermal energy in agriculture and in industry is less propagated compared with its use in Cretan buildings.

\section{B. Solar Photovoltaic Energy}

Solar-PV systems have grown rapidly during the last decade in Crete generating significant amount of electricity. Many of them have been installed in grid connected buildings, rated at 3-10 KWp, generating electricity 
according to "green-roof" and "net-metering" initiatives. Some solar-PV systems have been also installed in off-grid buildings and in other uses, including lighthouses and mobile telephone's antennas, located in remote areas. Many solar-PV systems, rated at $80-100 \mathrm{KWp}$, have been also installed in agricultural land in Crete generating electricity injected into the grid with pre-agreed feed-in tariffs. During 2018 the nominal power of the solar-PVs installed in the fields in Crete was at $78 \mathrm{MWp}$ while the installations in building's roofs were at $17.50 \mathrm{MWp}$, totally at 95.50 MWp. In 2018 solar electricity generation in the island was at 134,808 MWh contributing at $4.43 \%$ in the total electricity generation.

\section{Other Solar Energy Applications in Crete}

Solar thermal cooling technology is desirable in Crete since space cooling in buildings is required in the summer during the period of high solar irradiance. During the previous years, two solar thermal cooling systems have been installed in hotels in Crete. However, the experience from their operation was not satisfactory and the technology has not been further promoted. It seems that the current status of solar thermal cooling technology is not mature yet and technological advances are needed to facilitate its future penetration into the market. Apart from the use of solar thermal cooling systems in Crete efforts have been made in the past for the installation of solar thermal power plants rated at 20-50 MW. These efforts have not succeeded so far while new licenses for the installation of solar thermal power plants in Crete have been currently approved by the government.

\section{WIND ENERGY APPLICATIONS}

\section{A. Wind Parks}

The wind energy resources in Crete are rich and the mean annual wind velocities in many locations are high. The current cost of wind generated electricity in the island is low compared with the cost of electricity derived from fossil fuels. Wind parks have been developed during the last two decades in the island mainly in hilly and mountainous areas with power at 2-10 MW each. Off-shore wind parks are not developed so far due to the flourishing tourism industry in Crete and to the fact that island's coasts and the sea are used for recreational reasons. The current total installed power of wind parks in Crete is estimated, in 2018, at 200.3 MW while the wind electricity generation was at 510,059 MWh corresponding at $16.76 \%$ of the total annual electricity generation in the island. All the installed wind parks in Crete are located in rural areas. Further development of wind parks is limited due to the fact, that the island's electric grid is autonomous, and installation of more wind parks will threaten its stability. Electricity pump storage systems combined with wind parks have not been developed yet in Crete. However, the future interconnection of the island's electric grid with the grid of continental Greece is expected to increase the development of more wind parks in Crete.

\section{B. Small Wind Turbines}

Installation of small wind turbines rated at $100 \mathrm{~W}$ to 20 $\mathrm{KW}$, in Crete is so far limited although the mean annual wind speeds in many locations are high. Some of them have been already installed combined with solar-PV systems and diesel generators generating electricity for residential buildings or other consumers located in remote areas without electric grid infrastructure. Unfortunately, their use in residential buildings or in hotels is not currently allowed according to net-metering regulations like solar-PVs. Additionally, the technology of very small wind turbines which could be used in residential buildings is not broadly commercialized yet. However, their use is expected to increase in the future after the interconnection of the electric grid of Crete with the grid of continental Greece and improvements in existing technology.

\section{BIOMASS APPLICATIONS}

\section{A. Solid Biomass}

Solid biomass is broadly used for heating purposes in rural areas in Crete. Biomass used is mainly produced from cultivated trees while the use of forest biomass is rather limited. Due to existing olive trees orchards in the island, olive tree wood, olive tree pruning, and olive kernel wood are used for heating in residential buildings, greenhouses and small size industries located in rural areas processing agricultural products. Heat generation systems include wood stoves, fireplaces and other biomass burning systems. Solid biomass is not currently used in Crete for electricity generation or co-generation of heat and power. Solid biomass heating using local resources is currently cheaper compared with heating with conventional fuels in Crete.

\section{B. Biogas}

Small quantities of biogas are currently produced in Crete from a) digestion of the sludge in the sewage treatment plants in the cities of Chania and Heraklion and b) digestion of agricultural and other organic wastes in a plant located in Eastern Crete. The power of each installation is lower than $500 \mathrm{KW}$. Biogas produced is burnt and the electricity generated is fed into the grid with pre-agreed feed-in tariffs. Biogas is not currently produced in existing landfills in Crete. However, it is predicted that this will change in the future. There is an increasing interest regarding the creation of new biogas producing plants in Crete from the digestion of various organic wastes as well as agricultural residues and probably its production will be increased in the future.

\section{HYDRO ENERGY APPLICATIONS}

Use of hydro energy for electricity generation is limited in Crete. There are two tiny hydroelectricity plants located in rural areas in Western Crete with installed power at $300 \mathrm{KW}$ each. Their contribution in the annual electricity generation in Crete is rather negligible. During 2018 the electricity generation was at $257 \mathrm{MWh}$ contributing at $0.01 \%$ in the total annual electricity generation. Construction of a larger hydroelectricity plant is planned in central Crete which is 
going to utilize the water fall from an existing water storage dam in this area.

\section{GEOTHERMAL ENERGY APPLICATIONS}

Geothermal fluids of medium or high enthalpy, have not been found so far in the island of Crete. However high efficiency heat pumps are increasingly used for airconditioning in various types of buildings, including residential buildings, schools, hotels, and public buildings, located in rural areas. They can provide space heating and cooling as well as DHW production. Although their initial installation cost is high there are currently competitive to diesel oil heating due to their high energy efficiency. Use of high efficiency heat pumps, having coefficients of performance higher than 3-4, is very important for the creation of nearly zero energy buildings, according to the current EU regulations necessary for climate change mitigation. Use of heat pumps in small size food processing industries as well as in greenhouses located in rural areas in Crete is rather limited. Existing applications of REs in rural areas in Crete are presented in Table 1. The installed power of various renewable energy systems and the electricity generation from them are presented in Table 2.

TABLE 1: RENEWABLE ENERGY APPLICATIONS IN RURAL AREAS IN CRETE

\begin{tabular}{|c|c|c|c|}
\hline $\begin{array}{c}\text { Renewable } \\
\text { energy }\end{array}$ & Technology used & $\begin{array}{l}\text { Energy } \\
\text { produced }\end{array}$ & Applications \\
\hline Solar energy & $\begin{array}{l}\text { Solar thermal } \\
\text { systems }\end{array}$ & Hot water & $\begin{array}{l}\text { DHW in } \\
\text { buildings }\end{array}$ \\
\hline Solar energy & Solar-PV panels & Electricity & $\begin{array}{l}\text { Electric grid, self- } \\
\text { consumption }\end{array}$ \\
\hline Wind energy & Wind turbines & Electricity & $\begin{array}{l}\text { Electric grid, self- } \\
\text { consumption }\end{array}$ \\
\hline Hydro energy & $\begin{array}{l}\text { Water dams- } \\
\text { Hydro turbines }\end{array}$ & Electricity & Electric grid \\
\hline Solid biomass & Burning & Heat & $\begin{array}{l}\text { Buildings, } \\
\text { industry, } \\
\text { greenhouses }\end{array}$ \\
\hline $\begin{array}{c}\text { Biogas } \\
\text { produced from } \\
\text { digestion of } \\
\text { agricultural or } \\
\text { other organic } \\
\text { wastes }\end{array}$ & Burning & $\begin{array}{l}\text { Heat, } \\
\text { electricity }\end{array}$ & $\begin{array}{c}\text { Various heat } \\
\text { uses, electric grid }\end{array}$ \\
\hline $\begin{array}{l}\text { Low enthalpy } \\
\text { geothermal } \\
\text { energy }\end{array}$ & $\begin{array}{l}\text { High efficiency } \\
\text { heat pumps }\end{array}$ & Heat, cooling & $\begin{array}{l}\text { Buildings, } \\
\text { industry }\end{array}$ \\
\hline
\end{tabular}

Source: Own data.

TABLE 2: INSTALLED POWER OF VARIOUS RENEWABLE ENERGY SYSTEMS AND ELECTRICITY GENERATION IN CRETE (2018) 1,2 $^{1,2}$

\begin{tabular}{|c|c|c|c|c|}
\hline $\begin{array}{c}\text { Renewable } \\
\text { energy }\end{array}$ & $\begin{array}{c}\text { Generated } \\
\text { energy }\end{array}$ & $\begin{array}{l}\text { Installed } \\
\text { power }\end{array}$ & $\begin{array}{c}\text { Amount of } \\
\text { generated } \\
\text { electricity } \\
(\mathrm{MWh})\end{array}$ & $\begin{array}{l}\% \text { of total } \\
\text { electricity } \\
\text { generation }\end{array}$ \\
\hline Solar energy & Electricity & $95.5 \mathrm{MW}_{\mathrm{p}}$ & 134,808 & 4.43 \\
\hline Solar energy & Heat & $\begin{array}{l}186.4 \\
\mathrm{MW}_{\text {th }}\end{array}$ & & \\
\hline Wind energy & Electricity & $\begin{array}{l}200.3 \\
\mathrm{MW}_{\mathrm{el}}\end{array}$ & 510,059 & 16.76 \\
\hline $\begin{array}{c}\text { Hydro energy } \\
\text { Total }\end{array}$ & Electricity & $0.6 \mathrm{MW}_{\mathrm{el}}$ & 257 & 0.01 \\
\hline installed & & 296.4 & & \\
\hline $\begin{array}{l}\text { electric } \\
\text { power }\end{array}$ & & $\mathrm{MW}_{\mathrm{el}}$ & & \\
\hline
\end{tabular}

${ }^{1}$ HEDNO, 2018, ${ }^{2}$ Own estimations.

\section{FUTURE APPLICATIONS OF RENEWABLE ENERGIES IN RURAL AREAS IN CRETE}

Future developments of new RE applications in rural areas in Crete include:

a) Use of solar thermal energy for power generation. Licenses for installation of solar thermal power plants have been already approved in Crete,

b) Use of solar thermal cooling applications. Improvements in the existing solar thermal cooling technology will allow its future use in Crete,

c) Exploitation of existing agricultural residues and wastes with anaerobic digestion for biogas production and biogas use for heat and power generation,

d) Cultivation of energy crops and use of the produced biomass for bio-fuels production,

e) Combined use of wind farms and hydro pump storage systems for electricity generation, and

f) Use of solar and wind electricity for water electrolysis and hydrogen production as carbon neutral fuel according to EU policies for the promotion of hydrogen economy.

Additionally, due to the increasing interest from many investors, more applications of the existing RE technologies are expected in the near future in Crete when the interconnection of the island's electric grid with the continental country's grid will allow the installation of more solar and wind electricity generation plants.

The new RE systems that could be used in the future in rural areas in Crete are presented in Table 3.

TABLE 3: NEW RENEWABLE ENERGY SySTEMS THAT COULD BE USED IN THE FUTURE IN RURAL AREAS IN CRETE

\begin{tabular}{ccc}
\hline Renewable energy & Solar thermal & $\begin{array}{c}\text { Generated } \\
\text { energy/fuel }\end{array}$ \\
\hline $\begin{array}{c}\text { Solar energy } \\
\text { Solar energy } \\
\text { Biomass }\end{array}$ & $\begin{array}{c}\text { Solar thermal } \\
\text { Solar thermal } \\
\text { Digestion } \\
\text { Chemical and } \\
\text { biological } \\
\text { processing }\end{array}$ & $\begin{array}{c}\text { Electricity } \\
\text { Cooling energy } \\
\text { Biogas }\end{array}$ \\
Biomass & Biogas \\
$\begin{array}{c}\text { Hydroelectric } \\
\text { combined with } \\
\text { wind energy }\end{array}$ & $\begin{array}{c}\text { Wind farms and hydro } \\
\text { turbines }\end{array}$ & Electricity \\
$\begin{array}{c}\text { Solar and wind } \\
\text { energy }\end{array}$ & $\begin{array}{c}\text { Water electrolysis } \\
\text { using solar and } \\
\text { wind electricity }\end{array}$ & Hydrogen \\
\hline \hline
\end{tabular}

\section{DISCUSSION}

Our results indicate that many mature, reliable and costeffective RE systems have been currently installed in rural areas in Crete generating heat and electricity while higher development is predicted in the future particularly when the electric grid of Crete will be interconnected with the continental grid of Greece. The results indicate that various zero carbon emissions energy technologies could cover the majority, if not all, of the island's annual energy needs reducing its carbon emissions into the atmosphere complying with the global targets for climate change mitigation. REs use promotes the development of distributed energy generation systems in Crete resulting in many 
benefits regarding the stability of the electric grid as well as in the increase of energy security and self-sufficiency. Their use also promotes new green investments and assists in new jobs creation in rural areas. Use of indigenous renewable natural resources replacing imported exhaustible fossil fuels contributes to the increase of island's environmental sustainability. Our work indicates that the transition of Crete's economy to low or zero carbon economy is not only desirable but also feasible exploiting the local abundant renewable energy resources. Other smaller or larger islands in Mediterranean region could also utilize their rich renewable energy resources to facilitate their transition in a low carbon and more sustainable economy increasing the prosperity in their societies.

\section{COnClusions}

Use of renewable energy systems in rural areas in Crete has been presented. Due to the rich solar and wind energy resources in Crete many solar-PV systems and wind farms have been already installed generating more than $20 \%$ of the annual electricity consumption in the island. The fact that the electric grid in Crete is autonomous restricts the installation of more solar and wind electricity generation systems. Apart from solar-PV systems and wind farms already installed in rural areas in Crete other RE applications include the use of solar thermal systems for DHW production, use of small hydro electricity generation systems, use of high efficiency heat pumps for airconditioning in buildings as well as use of solid and gaseous biomass for heat and power generation. Future uses of different RE technologies in rural areas in Crete are predicted including the use of solar thermal energy for electricity generation and space cooling, use of biomass for generation of electricity and bio-fuels, use of water dams for electricity generation as well as the production of hydrogen with water electrolysis using solar and wind electricity. The results are important since they indicate that the high potential of indigenous REs in Crete, like in other Mediterranean islands, could contribute in de-carbonization of the island's economy, reduction of its carbon footprint, promotion of energy investments, creation of new local jobs as well as in the reduction of the imported fossil fuels currently used. Further research should be focused in the investigation of the possibility of zeroing carbon emissions due to energy use in the island of Crete complying with the EU target for zero carbon emissions by 2050 and the global efforts for mitigation of climate change.

\section{REFERENCES}

[1] R. Ciriminna, M. Pagliaro, F. Meneguzzo, \& M. Peoraino, "Solar energy for Sicily's remote islands: On the route from fossil to renewable energy", International Journal of Sustainable built Environment, Vol. 5, pp. 132-140, 2016 http://dx.doi.org/10.1016/j.ijsbe.2016.04.003.

[2] V. Franzitta, D. Gurto, \& D. Rao, "Energetic sustainability using renewable energies in the Mediterranean Sea", Sustainability, 8, 1164, 2016. doi:10.3390/su8111164.

[3] I. Kougias, S. Szabo, A. Nikitas, \& N. Theodosiou, "Sustainable energy modeling of non-interconnected Mediterranean islands",
Renewable Energy, Vol. 133, pp. 930-940, 2019. https://doi.org/10.1016/j.renene.2018.10.090.

[4] EU islands in the energy transition. A catalogue of good practices, Clean Energy for EU Islands, 2019. Available: https://euislands.eu/euislands-good-practices.

[5] I. Efthymiopoulos, "Islands as test beds for innovative energy solutions", Seminar held in Athens, Greece, November 9-10, 2015.

[6] Tsekeris, D. (2019). The energy transition of the Greek noninterconnected islands, Greek Ministry of Environment and Energy. Available: https://hybridpowersystems.org/crete2019/downloads/.

[7] O. Christopoulou, M. Fountoukidou, St. Sakellariou, St. Tampekis, F Samara, A. Sfoungaris, A. Stergiadou, G. Tsantopoulos, K. Soutsas, \& I. Sfoungaris, "Energy Autonomy in Small Islands in the Frame of Their Sustainable Development Exploring Biomass Energy Potential in Samothrace (Greece)", International Journal of Sustainable and Green Energy. Special Issue: Advances in Sustainability Assessment, Vol. 6(4-1), pp. 9-17, 2015. doi: 10.11648/j.ijrse.2015060401.12.

[8] Ch. Ioakimidis, \& K.N. Genikomsakis "Integration of seawater pumpstorage in the energy system of the island of Sao Miguel (Azores)", Sustainability, Vol. 10, 3438, 2018. doi:10.3390/su10103438.

[9] H. Dorotic, B. Dorasic, V. Dobravec, T. Puksec, G. Krajacic, \& N Duic, "Integration of transport and energy sectors in island communities with $100 \%$ intermittent renewable energy sources", Renewable and Sustainable Energy Reviews, Vol. 99, pp. 109-124, 2019. https://doi.org/10.1016/j.rser.2018.09.033.

[10] G. Mihalakakou, B. Psiloglou, M. Santamouris, \& D. Nomidis, "Application of renewable energy sources in the Greek islands of the South Aegean Sea", Renewable Energy, Vol. 26(1), pp. 1-19, 2002. https://doi.org/10.1016/S0960-1481(01)00111-2.

[11] Renewable energy on islands: a pathway to prosperity, Climate Action, 2015. Available: http://www.climateaction.org/climateleader-

papers/renewable_energy_on_islands_a_pathway_to_prosperity.

[12] Z. Gkouskos, \& Th. Tsoutsos, (September 2011). Solar application in the island of Crete. Examples of the renewable and sustainable energy lab, Technical University of Crete, in International Conference BIOSOL, Crete, Greece.

[13] A. Gigantidou, (August, 2013). Renewable energy sources in Crete. IREP Symposium - Bulk Power System Dynamics and Control. IX (IREP), Rethymno, Crete, Greece. Available: http://papers.irep2013.ntua.gr/83.pdf

[14] I. Kougias, K. Bodis, A. Jager-Waldau, M. Moner-Girona, F. Monforti-Ferrario, H. Ossenbrink, \& S. Szabo, "The potential of water infrastructure to accommodate solar-PV systems in Mediterranean islands", Solar Energy, Vol. 136, pp. 174-182, 2016 http://dx.doi.org/10.1016/j.solener.2016.07.003

[15] D. Katsaprakakis, I. Antonakakis, I., Dakanali, \& D. Christakis, (May 2019). Turning Crete into an energy independent island. $4^{\text {th }}$ International Hybrid Power Systems workshop, Crete, Greece. Available:

https://www.researchgate.net/publication/333701601_Turning_Crete into_an_energy_independent_island.

[16] J. Vourdoubas, "Present and future use of biomass for energy generation in the island of Crete, Greece", Journal of Energy and Power Sources, Vol. 2(4), pp. 158-163 2015.

[17] S. Alatzas, K. Moustakas, D. Malamis, \& S. Vakalis, "Biomass potential for agricultural waste for energetic utilization in Greece", Energies, Vol. 12, 1095, 2019. doi:10.3390/en12061095.

[18] T. Nikolaou, G.S. Stavrakakis, \& K. Tsamoudalis, "Modeling and optimal dimensioning of a pumped hydro energy storage system for the exploitation of the rejected wind energy in the non-interconnected electrical power system of the Crete island, Greece", Energies, Vol. 13, 2705, 2020. doi:10.3390/en13112705.

[19] Reinforcing investments in biogas technologies for small scale RES applications in islands, BIORES, Intelligent Energy Europe. Available: https://ec.europa.eu/energy/intelligent/projects/en/projects/biores

[20] J. G. Fantidis, D. V. Bandekas, N. Vordos, \& S. Karachalios (January-February 2013). Wind energy potential in Greece using a small wind turbine, Recent Advances in Energy, Environment and Development, Cambridge, Available: https://www.researchgate.net/publication/257929879_Wind_Energy_ Potential_in_Greece_Using_a_Small_Wind_Turbine.

[21] Annual report on the energy system in Crete, (2018), Hellenic Electricity Distribution Network Operator (DEDDIE), (in Greek).

[22] A. A. Argiriou, \& S. Mirasgedis, "The solar thermal market in Greece - review and perspectives", Renewable and Sustainable Energy 
Reviews, Vol. 7(5), pp. 397-418, 2003. https://doi.org/10.1016/S13640321(03)00064-9.

[23] M. Karagiorgas, A. Botzios, \& Th. Tsoutsos, "Industrial solar thermal applications in Greece: Economic evaluation, quality requirements and case studies", Renewable and Sustainable Energy Reviews, Vol. 5(2), pp. 157-173, 2001. https://doi.org/10.1016/S13640321(00)00012-5.

[24] N. Scarlat, J-F. Dallemand, \& F. Fahl, "Biogas: Developments and perspectives in Europe", Renewable Energy, Vol. 129, pp. 457-472, 2018. https://doi.org/10.1016/j.renene.2018.03.006.

[25] Raboni, M. \& Urbini, G. (2014). Production and use of biogas in Europe: a survey of current status and perspectives, Ambiente \& Agua - An interdisciplinary Journal of Applied Science, 9(2), 191202. doi: 10.4136/ambi-agua. 1324

[26] V. Aggarwal, Ch. Swaroop Meena, Ash. Kumar, T. Alam, An. Kumar, Arij. Ghosh, \& Arit. Ghosh, "Potential and future prospects of geothermal energy in space conditioning of buildings: India and worldwide review", Sustainability, Vol. 12, 8428, 2020. doi:10.3390/su12208428

[27] Off-grid renewable energy systems: Status and methodological issues,
IRENE,
2015
Available:

https://www.irena.org/publications/2015/Feb/Off-grid-renewableenergy-systems-Status-and-methodological-issues.

[28] J. W. Lund, T. L. \& Boyd, (April 2015). Direct utilization of geothermal energy 2015, Worldwide View, Proceedings World Geothermal Congress Melbourne, Australia. Available: https://www.unionegeotermica.it/pdfiles/usi-diretti-energiageotermica-nel-mondo.pdf.

[29] Biomass production, supply, uses and flows in the European Union (2018), JRC Science for Policy report. Available: https://ec.europa.eu/jrc/en/publication/eur-scientific-and-technicalresearch-reports/biomass-production-supply-uses-and-flowseuropean-union-first-results-integrated-assessment.

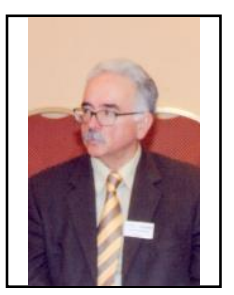

John S. Vourdoubas was born in Crete, Greece in 1952, is Chemical Engineer, National Technical University of Athens, Greece, M.Sc., Loughborough University of technology, England, Ph.D., Hull University, England. He was lecturing during the last 25 years in Mediterranean University of Crete, Greece in the field of sustainable energy technologies and he was research collaborator in Mediterranean Agronomic Institute of Chania, Greece. Dr. Vourdoubas has been actively participated in many EU funded research projects and he is author and co-author of many papers, in the fields of renewable energy technologies and in environmental sustainability, published in various international scientific journals. 